\title{
Life cycle thinking in Polish official documents and research
}

\author{
The determination of discount rate for green public procurement
}

\author{
Joanna Kulczycka
}

Received: 5 February 2009 /Accepted: 5 May 2009/Published online: 4 June 2009

(C) Springer-Verlag 2009

In Poland, the idea of implementing the methodology of life cycle thinking has been present in many official documents, i.e., ecological policy, development strategy, and even in the environmental protection law since the year 2001. The proposal of utilizing life cycle thinking included the assessment of new technologies, green public procurement, waste management and ecolabeling. In the successive yearstogether with the development of the strategy for implementing integrated product policy in Poland-its special importance was emphasized when an LCA was developed for a group of products characterized by high material consumption and waste production. At present, when applying for subsidies from structural funds in the Innovative Economy Operational Program, the decrease in harmful actions, limited energy, material and water consumption of products and services are in the focus of evaluation. Another criterion is the use of life cycle assessment. The proposal to use LCA can be found in the following documents in Poland:

1. Environmental Protection Law-the Act of April 27, 2001 (Law Gazette No. 62, item 627) In article 143 concerning the requirements to be fulfilled in the case of new technologies used in newly started or significantly modified installations or devices, it is stated that they should apply product life cycle assessment. However, this regulation was valid only until May 18, 2005 when it was repealed by the Act changing the Environmental Protection Law.

\footnotetext{
J. Kulczycka $(\bowtie)$

Mineral and Energy Economy Research Institute of the Polish

Academy of Sciences or (MEERI PAS),

ul. Wybickiego 7 ,

31-261 Kraków, Poland

e-mail: kulczycka@meeri.pl
}

2. II State Ecological Policy, accepted by the Council of Ministers in June 2000 and the Polish Parliament in August 2001 In Chapter 1, "Initial Assumptions", item 1.4 "Ecologization of the sector policies", considering the methods for realizing the state ecological policy, it is said that priority will be given to the "good management practices" and environmental management systems which make it possible to combine economic and ecological effects. Particularly in industry and power engineering, the realization of product life cycle-oriented policy is expected to limit the amount of waste produced. In Chapter 2, "Goals of the ecological policy regarding the rational use of natural resources", item 2.2 on "Decreasing the material consumption and process waste production", there is a regulation concerning mean-term goals (until 2010) which broadly popularizes product life cycle assessment including environmental impact assessment. A further mean-term goal is the implementation of the statutory duty to perform such assessments for groups of products characterized by high material consumption and waste production as well as products containing hazardous substances. In Chapter 3, "Goals of the ecological policy regarding the environmental quality", item 3.1. on "Waste Management", it is documented that the principle of sustainable development and integrated approach to environmental protection, including the problems of responsibility, constitute the main policy line as regards waste management. The overriding goal of waste management policy is to prevent waste production by solving the problem of waste at its source, which means to recover raw materials, to re-use waste products, and to dispose unusable waste in a manner that is safe to the environment. The realization of this 
goal requires a decrease in industrial material and energy consumption, the use of clean technologies, the use of alternative, renewable sources of energy, and the assessment of the whole product life cycle (production, transport, packaging, use, possible re-use and disposal). Item 3.3 on "Air quality. Climate changes" states that the characteristics of the new policy regarding air pollution control are actions such as the implementation of product standards limiting the emission of pollutants resulting from the whole product life cycle - starting with raw material extraction and its processing, via the manufacturing of new products and their use, and ending in the transition to the waste form ${ }^{1}$.

3. State Ecological Policy for the years 2003-2006 including the prospects for the years 2007-2010 published in December 2002. Chapter 3, "Sustainable use of raw materials, water and energy as the task for the years 2003-2006", introduces the duty to assess the life cycle of selected products.

4. Strategy for changing production and consumption models to those favoring the realization of constant, sustainable development principles ${ }^{3}$ - a governmental document, elaborated by the Ministry of Economy, Labor and Social Policy, and accepted by the Council of Ministers on October 14, 2003. It is proposed to support investments in environmental protection, to include Life Cycle Assessment (LCA) and Environmental Product Declarations (EPD).

5. Strategy for implementing the integrated product policy into Poland ${ }^{4}$. This document was elaborated on by the Ministry of the Environment and accepted by the European Committee of the Council of Ministers on February 25, 2005. The realization of this strategy in Poland includes:

- research and expertise, e.g., legal and institutional changes for using economic instruments for environmental protection, application of green public procurement, analysis and assessment of the possibility to introduce pro-ecological tax reform in Poland, introduction of ecological accounting in Poland using life cycle perspective, making life cycle information and interpretative tools available, cost internalization and its influence on economy competitiveness;

\footnotetext{
$\overline{1}$ www.mos.gov.pl/2materialy_informacyjne/raporty_opracowania/ pol_ekoII_nowy/1pep.htm

${ }_{2}$ www.mos.gov.pl/polityka_ekologiczna/

${ }^{3}$ www.mg.gov.p1/Wiadomosci/Archiwum/Lata+2002-2004/Strategia + zmian+wzorcow + produkcji $+\mathrm{i}+\mathrm{konsumpcji}+$ na + sprzyjajace + realizacji+zasad+trwalego+z.htm

${ }^{4}$ www.mos.gov.pl/sipw/zintegrowana_polityka_produktowa/ strategia_ZPP.pdf
}

- promotion and education actions - conferences, seminars, e.g., on eco-labeling, EMAS, etc.;

- coordination actions.

6. The Road Map for Implementing the Environmental Technologies Action Plan (KETAP) in Poland was published by the Ministry of the Environment in $2006^{5}$. The chapter on public procurement presents the tasks of environmental technologies, i.e.:

- encouraging the conclusion of public procurement contracts ensuring the use of environmental criteria and new environmental technologies;

- promoting the use of product / service life cycle assessment.

7. The importance of the life cycle method has been stressed in the Country Development Strategy for the Years $2007-2015^{6}$ which was accepted by the Council of Ministers on November 29, 2006. The strategy discusses the importance of eco-innovations-including support to investment activities / organizational solutions - and spatial management methods. At the same time, the realized activities should lead to: fundamental limitations regarding the use of natural resources per unit of product or service, replacement of non-renewable resources by renewable resources, considerable limitation of pollutants emitted into air, water and soil, decrease in the degradation of the environment and reduction of the noise level.

8. Entrepreneurs who apply for financial assistance from the EU funds in the years 2007-2013, within the Innovative Economy Operational Program ${ }^{7}$, should demonstrate the effects of decreased environmental impacts resulting from limited energy, material and water consumption of products and services, and the use of Life Cycle Assessment at all stages of technological process design.

9. State Ecological Policy for the years 2007-2010 including prospects for the years 2011-2014 ${ }^{8}$ was elaborated on by the Ministry of the Environment in December 2006. Chapter 2, "Development of the system for assessing influences in the product life cycle and estimating...", states that the improvement of the environmental management system consists of developing a system for assessing influences in the product life cycle and estimating material flows, which are the elements of the Integrated Product Policy.

\footnotetext{
5 www.mos.gov.pl/2strony_tematyczne/etap/wdrazanie/mapa drogowa_POL.pdf

6 www.mrr.gov.pl/srk/

${ }^{7}$ www.mrr.gov.pl/ProgramyOperacyjne+2007-2013/Innowacyjna +Gospodarka/

${ }^{8}$ www.mos.gov.pl/polityka_ekologiczna/
} 
Besides the regulations in official documents, the LCA method was used mainly by scientific institutions and universities. First research works (since 1986) concerning mainly machines and devices were carried out at Poznan University of Technology by Prof. Zbigniew Klos. One of the effects of these works was the first book on LCArelated issues, published in 1990 (Klos 1990). Other research institutions are:

1. Poznan University of Economics where LCAs were carried out also for industries, e.g., pumps and wood products. As a result, two books in Polish were published (Lewandowska 2006; Strykowski et al. 2006).

2. Mineral and Energy Economy Research Institute of Polish Academy of Sciences in Krakow. This institute cooperates with different industries, e.g., copper and zinc producers. As a result, two books in Polish appeared (Kulczycka 2001; Kowalski et al. 2007) about the application of LCA for different products and processes.

3. Other institutions are: Zielonogórski University, Central Mining Institute, Institute for Building Technology.

As regards the use of LCA in industry, this is done first of all by branches of international companies such as ABB (1st in Poland type III product declaration), $3 \mathrm{M}$, Volvo, Saint Gobain Isover Polska (2nd in Poland type III product declaration). These inform about their products and strategies based on LCA.

More detailed information about LCA activities in Poland can be found in Zeszyty Naukowe Politechniki Poznańskiej No 62, Poznań 2007, published in English (PUT 2007).

Since 2007, the idea of the life cycle has been promoted by central offices. The Ministry of Economy published a brochure about LCA, and the Public Procurement Office provides training courses on LCA and LCC. Special attention focuses on the application of these methods to green public procurement. The results of the study performed by order of the European Commission as well as the studies carried out at the Public Procurement Office show that environmental aspects are still rather disregarded in public procurement. In spite of the fact that the idea and examples of using LCC in public procurement are widely documented, also by order of the European Commission, the issue of the proposed discount rate in calculating the Life Cycle Costing was discussed in detail during the training courses.

The application of discounting in LCC calculations has been described in detail in a paper by Hellweg et al. (2003), where it was defined as valuing damages differently at different points in time using a positive or negative discount rate (taking into account pure time preference, productivity of capital, diminishing marginal utility of consumption and uncertainties). The problem of discounting can also be found in official EU documents. A method for calculating costs and discount rates was proposed for energy-using products, i.e., in Directive 2005/32/EC (2005) ${ }^{9}$. ANNEX II contains information about the proposed discount rate, i.e., "...concerning energy consumption in use, the level of energy efficiency or consumption will be set aiming at the life-cycle cost minimum to end-users for representative $\mathrm{EuP}$ models, taking into account the consequences on other environmental aspects. The life-cycle cost analysis [assessment] method uses a real discount rate on the basis of data provided from the European Central Bank (ECB) and a realistic lifetime for the EuP; it is based on the sum of the variations in purchase price (resulting from the variations in industrial costs) and in operating expenses, which result from the different levels of technical improvement options, discounted over the lifetime of the representative EuP models considered. The operating expenses cover primarily energy consumption and additional expenses in other resources (such as water or detergent)". Real discount rates on the basis of data provided by the ECB can probably be the key interest rate for the Euro area set by the ECB, i.e., main refinancing operations - the minimum bid rate amounted to $4 \%$ since 13 June 2007.

Besides, in the study done by order of the DG ENV.G.2/ SER/2006/0097, entitled Costs and Benefits of Green Public Procurement in Europe (2007) ${ }^{10}$, it has been pointed out that the discount rate is usually defined according to the long-term interest rate which best represents the costs for equity of public authorities. It has been stated that discounting is only relevant for those product groups where costs are incurred during the use phase or for the disposal of the regarded product (e.g., construction work, transport (buses, passenger cars), copiers / printers, computers, etc.). On the basis of harmonized long-term interest rates for convergence assessment purposes of the selected Member States published by the European Central Bank, the proposed common discount rate is set to be $4.40 \%$ for all selected Member States (December 2006-March 2007).

\footnotetext{
${ }^{9}$ Directive 2005/32/EC of the European Parliament and of the Council of July 6, 2005 establishes a framework for the setting of ecodesign requirements for energy-using products and amends Council Directive 92/42/EEC and Directives 96/57/EC and 2000/55/EC of the European Parliament and of the Council as well as DIRECTIVE 2008/28/EC of the European Parliament and of the Council of March 11, 2008 amending Directive 2005/32/EC, which establishes a framework for the setting of ecodesign requirements for energy-using products. Council Directive 92/42/EEC and Directives 96/57/EC and 2000/55/ $\mathrm{EC}$ are concerned with the implementation of powers conferred on the Commission (Official Journal of the European Union L 81/48, March 20, 2008)

${ }^{10}$ Costs and Benefits of Green Public Procurement in Europe by ÖkoInstitut and ICLEI for EC, July 2007, http://ec.europa.eu/environment/ gpp/index_en.htm
} 
In turn, in the Guide to cost-benefit analysis of investment projects prepared for Evaluation Unit DG Regional Policy European Commission (2002) ${ }^{11}$, there is a distinction between the financial discount rate and the economic rate. For the period 2000-2006, a 6\% financial rate was considered as the reference parameter for the opportunity cost of capital in the long term. In practice, a real financial discount rate of 6\% for 2001-2006 is not very far from two times the value of the real return on EIB bonds. This may be a convenient financial cut off rate for public projects, except in particular circumstances that must be justified by the project proposed. The discount rate in the economic analysis of investment projects (i.e., social discount rate) attempts to reflect the social view on how future benefits and cost should be valued against present ones. Usually, national governments set the social discount rate for public projects at a lower level than international financial institutions. In a new Guide to cost-benefit analysis of investment projects Structural Funds, Cohesion Fund and Instrument for Pre-Accession $(2008)^{12}$, the EC suggests a benchmark concerning a real financial discount rate of $5 \%$, whereas a real social discount rate suggested SDR benchmark values: 5\% for Cohesion and IPA countries and for Convergence regions elsewhere with high growth outlook; 3.5\% for "Competitiveness regions".
As the level of discount rate can have an influence on the overall ranking of alternative solutions (Hunkeler et al. 2008), and when using life cycle costing as a one of criteria in green public procurement, the official proposal of benchmark value for the discount rate level will significantly facilitate decision making, especially in the countries where the Euro has not yet been introduced.

\section{References}

Hellweg S, Hofstetter T, Hungerbuhler K (2003) Discounting and the environment. Should current impacts be weighted differently than impacts harming future generation? Int J Life Cycle Assess 8(1):8-18 2003

Hunkeler D, Lichtenvort K, Rebitzer G (ed) (2008) Environmental life cycle costing, SETAC, CRC Press, Taylor \& Francis Group

Klos Z (1990) Environmental protection oriented property of technical objects. A study of machines and devices influence on environment. Editions of PUT, Poznan (in Polish)

Kowalski Z, Kulczycka J, Góralczyk M (2007) LCA of industrial processes. Editions of PWN, Warsaw 2007 (in Polish)

Kulczycka J (ed) (2001) LCA-a new tool for environmental management. Editions of MEERI PAS, Kraców (in Polish)

Lewandowska A (2006) LCA for industrial pumps. Editions of AE Poznan (in Polish)

PUT Scientific Journal (2007) Machines and Transportation No 62. Poznan (in English)

Strykowski W et al. (2006) LCA for wood products. Editions of ITD Poznan (in Polish)

\footnotetext{
${ }^{11}$ Guide to cost-benefit analysis of investment projects (2002), ec. europa.eu/regional_policy/sources/docgener/guides/cost/guide02_en. pdf

${ }^{12}$ Guide to cost-benefit analysis of investment projects Structural Funds, Cohesion Fund and Instrument for Pre-Accession (2008) ec.europa.eu/ regional_policy/sources/docgener/guides/cost/guide2008_en.pdf
} 